\title{
Hellenistic Philosophy in Greek and Roman Times
}

\author{
Ioanna-Soultana Kotsori \\ University of Peloponnese, Kalamata, GREECE \\ Faculty of Humanities and Cultural Studies
}

Received 21 February 2019 • Revised 21 May 2019 • Accepted 11 June 2019

\begin{abstract}
The new Hellenistic philosophies that emerged in Athens at the end of the $4^{\text {th }}$ century BC - mainly Stoicism and Epicureanism - were largely non-original and second choice, compared to Plato and Aristotle. Unlike what happened with the works of Plato and Aristotle, the works of early Hellenistic era were lost on a large scale. However, they became the dominant philosophies of the next five centuries, and were extended from Greece to Rome and the distant provinces of the Roman Empire. A common element of the philosophers created in Hellenistic and Roman times is the connection of philosophy with individual life and its perception as an "art of life". Philosophy ends up being a driver of life and a source of relief, a healing art, a way to cope with a hostile world. From the $4^{\text {th }}$ century BC up to the first Christian centuries, Cynics, Stoics, Epicists and skeptical philosophers give a new role to philosophy.
\end{abstract}

Keywords: Stoicism, Epicureanism, Cynicism, Hellenistic era, Roman Empire.

\section{Introduction}

As professor Anthony A. Long says, in the early 1960s' there were two predominant ideas for Hellenistic philosophy. One was that the new Hellenistic philosophies that emerged in Athens at the end of the $4^{\text {th }}$ century BC - mainly Stoicism and Epicureanism - were largely nonoriginal, and second choice, compared to Plato and Aristotle. Unlike what happened with the works of Plato and Aristotle, the works of early Hellenistic era were lost on a large scale. Was not this a sign of their failure to withstand the test of time and consequently of their minor importance? The other prevailing idea was that these philosophies were doctrinal and practical guides in life, that they had been hurriedly and casually designed as a compass to help those who had lost their stamina as a result of the loss of autonomy and prosperity of Greek cities after conquests of Alexander the Great.

Long quickly realized that, as others have now realized, these two prevailing opinions were completely wrong. The Greek world at the end of the $4^{\text {th }}$ century was a highly prosperous community. What distinguished it from the pre-Alexandrian era was cosmopolitanism and the opening of borders to immigrants from Asia and Egypt. The new philosophies that developed in Hellenistic Athens, especially Stoicism and Epicureanism, were not only non-original, secondclass and minor, but they became the dominant philosophies of the next five centuries, and were extended from Greece to Rome and the distant provinces of the Roman Empire. The loss of most Hellenistic texts is not a criterion of their low quality, but a historical accident explained by the courses of the European and Byzantine monasteries that maintained the Rule of the Greek

(C) Authors. Terms and conditions of Creative Commons Attribution 4.0 International (CC BY 4.0) apply. Correspondence: Ioanna-Soultana Kotsori, University of Peloponnese, Faculty of Humanities and Cultural Studies, Kalamata, GREECE. E-mail: ioannakotsori@gmail.com. 
Secretariat, which is still in force today.

The originality of Hellenistic philosophies and the central element of their success were the fact that they focused their attention on appeasement and pluralism on the challenge that these philosophies offered people to choose their way of life and understanding nature rather than just comply with the tradition and conventions of their culture. Becoming a Stoic or Epicurean was indeed a great thing - a decision about what to do with your life with all its personal, family, social and professional effects. These two schools offered radically different spiritual orientations, theologies, value systems, and emotional support concepts. For Plato and Aristotle there was only one philosophy - the theory and practices taught at the Academy and the Lyceum. These schools continued their activity during the Hellenistic period, but they were now disadvantaged and overcome by the new philosophical movements I just mentioned. The dominant choices were twofold, between the epicurean life of araxia and the stoic life of "perfecting our rational nature".

\section{Stoicism}

Stoicism was a philosophical school of Hellenistic and Roman times. It has been one of the most important philosophical systems in Hellenistic philosophy. Their philosophy was formed over a period of more than four centuries, which is why it has taken on changes in the focus of its original interest, from the figures involved in Stoicism. According to surveys, it was set up in a troubled era to deal with it. For this reason, Stoicism as an anthropocentric content philosophy focused on the moral integrity of man. His representatives supported logic as a foundation stone for a virtuous and happy life. The latter seem to have been influenced by Socrates and his students (Zeller, 1923: 12-15).

Today, many works of the Stoics have not survived but only some of the writings of Seneca, Epiktitos and Marcus Aurelius. The Stoic school in Athens was founded in the $3^{\text {rd }}$ century $\mathrm{BC}$ by Zenon the Kition, who has been a significant presence in Hellenistic philosophy for about six centuries. In the beginning, the Stoic philosophers were called "Zenonioi", because of Zeno as the original tutor of the Stoic school. Then they were called "Stoics" or "Stoa philosophers" as Zeno's apprentices watched his traditions at the Poikilis Stoa, a public building of the Athenian Agora, decorated with colorful frescoes by famous artists of the time. The main representatives were Zenon the Kition, Cleanthis and Chrysippus, Panaitios, Posidonios, and in the imperial stoicism the most basic representatives were Seneca, Epiktitos and Marcus Aurelius (Benatouil, 2009: 222).

Stoicism evolved from the Cynic School, a school founded by Socrates' student Antisthenes. Although the interest of the Stoics differed according to the representatives of each time period, the teaching of morality was maintained from the beginning until the end of the Stoic teaching (Long, 1986: 115). It is worth noting that stoicism began as a cure against the passions of man and then acquired a philosophical substance. The eradication of passions lies in the pedagogical role of stoic morality. The Stoics were absolute about the expulsion of passions. The Stoic representatives of the first period are examples of temperance towards their passions. That is why many kings of that era called Stoic philosophers as advisors to the state or to educate their children. Ensuring apathy is difficult and sometimes cruel and inhumane, as man reacts in certain situations, freezing and indifferent, without being influenced by any emotion, such as death, which causes painful feelings. The wise man is at the same time the happy (Sharpe, 2013: 28-41).

In stark contrast to the Epicureanism, Stoic cosmology finds our world very orderly, well-structured to be a product of fortune or mechanical causes. The Stoics taught that only a superhuman mind could be the creator of this world. However, the Stoic deity is not, as claimed by Judaism and Christianity, transcendent, above nature, a creator who creates from nothing. Following the example of Plato, the Stoics saw the world as a gigantic organism, saturated with God as an energetic and vital energy that permeates everything. The Stoic God combines the idea 
of a superhuman and creative mind with the idea of an infinite source of energy. In their cosmology the world is both matter and spirit (Sellars, 2006: 32).

Some Epicureans had sought independence from the pressures of conventional society, living in small communities. The Stoics, however, saw all communities as examples of how the ecumenical mind extends throughout the world, while being present in a particularly sophisticated way within our human nature. In the eyes of the Stoic everywhere, all people are relatives of each other. This affinity is due to the fact that we all share the same nature, not only physically but also spiritually. The basis of this common nature is our ability to talk and think. Why is there war and political controversy? Because, according to the Stoics, human beings generally fail to realize their common nature and membership of the global community (Graver, 2009: 88).

This teaches us that it is absurd for people who have a common, rational nature, and common interests to treat one another as foreign and exploitable. As a Stoic, you cannot combine irrationality with happiness. Given these starting points, Stoics rejected the naturalness of slavery and all forms of discrimination based on nationality, gender, wealth, social status, physique and reputation. In this philosophy of life, the long-term happiness of a person does not depend on race, birth, income, appearance or success in events outside the ego. Happiness lies solely in the duty of achieving inner and outer harmony, striving to adapt its rational activity to the benefit of all rational beings, to treat itself as the microcosm of the divine secular organization, to harmonize it according to the values of community and interdependence (Seddon, 2015: 217).

For a Stoic, bliss is incompatible with passion, but it is not (as most people present Stoicism) a cold state of affairs. The ideal stoic mentality is positively joyful, but it does not suffer from an obsessive desire. For a Stoic, a life that is highly satisfying is based on the awareness that it is in harmony with nature, with the nature of each as a human being and the world in general. For a Stoic, bliss is harmony, symmetry - these are the transports that characterize the stoic virtue and its ability to make a "citizen of the world" according to the wonderful phrase they used (Seddon, 2015: 217).

Thus, the main emphasis of Stoicism as a philosophy of life is to give people a deep sense of who they are, how they relate to each other, and how they can form themselves so that they feel within the universe as if they were at home, even if much that they would prefer for themselves is not feasible. Other than the auxiliary, Stoics saw people as shareholders of the divine and creative vital force. This theological dimension, along with their cosmopolitanism, influenced early Christianity along with the indifference of religion for the accidental circumstances of birth and the locality of the people.

Stoicism gained great power and is recognized as one of the most supportive of Oratios, Cicero, Marcus Aurelius, who embraced the Stoic principles of duty and morality. The influence of Stoicism on representatives of modern European philosophy such as Spinoza, Cartesius, Kant, Locke, Goethe and others (Karakatsanis, 2002) was also important. Stoicism held a dominant position in the Hellenistic era, which, due to its influence, is entitled to place as a philosophical system of importance the corresponding Platonism and Aristotelism, greater impact on the ethical aspect of the duties of the individual, in the Roman society (Becker, 2001: 33).

\section{Epicureanism}

Epicureanism is a system of philosophy based upon the teachings of the ancient Greek philosopher Epicurus, founded around 307 BC. Epicurus believed that what he called "pleasure" ( $\dot{\eta}$ Soviं) was the greatest good, but that the way to attain such pleasure was to live modestly, to gain knowledge of the workings of the world, and to limit one's desires. This would lead one to attain a state of tranquility (ataraxia) and freedom from fear, as well as an absence of bodily pain 
(aponia). The combination of these two states constitutes happiness in its highest form. Although Epicureanism is a form of hedonism insofar as it declares pleasure to be its sole intrinsic goal, the concept that the absence of pain and fear constitutes the greatest pleasure, and its advocacy of a simple life, make it very different from "hedonism" as colloquially understood (Wilson, 2015: 93).

It was originally a challenge to Platonism, though later it became the main opponent of Stoicism. Influenced by Democritus, Aristotle, and possibly the Cynics, Epicurus turned against the Platonism of his day and established his own school, known as "the Garden", in Athens. He and his followers were known for eating simple meals and discussing a wide range of philosophical subjects, and he openly allowed women to join the school as a matter of policy. As evidence for this, Epicureans say that nature seems to command us to avoid pain, and they point out that all animals try to avoid pain as much as possible (Sharlpes, 1996: 84). Epicureans had a very specific understanding of what the greatest pleasure was, and the focus of their ethics was on the avoidance of pain rather than seeking out pleasure (O'Keefe, 2010: 117-121).

Epicureans believed that senses also relied on atoms. Every object was continually emitting particles from itself that would then interact with the observer. All sensations, such as sight, smell, or sound, relied on these particles. While the atoms that were emitted did not have the qualities that the senses were perceiving, the manner in which they were emitted caused the observer to experience those sensations, e.g. red particles were not themselves red, but were emitted in a manner that caused the viewer to experience the color red. The atoms are not perceived individually, but rather as a continuous sensation because of how quickly they move. An extremely prolific writer, he is said to have originally written over 300 works on various subjects, but the vast majority of these writings have been lost. Only three letters written by him - the Letters to Menoeceus, Pythocles, and Herodotus - and two collections of quotes - the Principle Doctrines and the Vatican Sayings - have survived intact, along with a few fragments and quotations of his other writings. His teachings are better recorded in the writings of later authors, including the Roman poet Lucretius, the philosopher Philodemus, the philosopher Sextus Empiricus, and the biographer Diogenes Laërtius. Epicurus and his followers shunned politics. After the death of Epicurus, his school was headed by Hermarchus; later many Epicurean societies flourished in the Late Hellenistic era and during the Roman era (such as those in Antiochia, Alexandria, Rhodes, and Ercolano). Its best-known Roman proponent was the poet Lucretius. By the end of the Roman Empire, being opposed by philosophies (mainly Neo-Platonism) that were now in the ascendant, Epicureanism had all but died out, and would be resurrected in the Age of Enlightenment (Wilson, 2015: 54-55).

The school's popularity grew and it became, along with Stoicism, Platonism, Peripateticism, and Pyrrhonism, one of the dominant schools of Hellenistic philosophy, lasting strongly through the later Roman Empire. Another major source of information is the Roman politician and philosopher Cicero, although he was highly critical, denouncing the Epicureans as unbridled hedonists, devoid of a sense of virtue and duty, and guilty of withdrawing from public life. Another ancient source is Diogenes of Oenoanda, who composed a large inscription at Oenoanda in Lycia (MacGillivray, 2012: 151-172).

\section{Cynicism}

Cynic was one of the longest-lasting philosophical schools in antiquity. Their school was founded by Antisthenes (445-360 or 444-368), son of an Athenian and a slave from Thrace, a distinguished warrior in the battle of Tanagra and later a student of Sophist Gorgios in Rhetoric, and then in philosophy of Socrates, to whose death he was present. The school was founded in the Cynogaras of Athens, the only high school in the city that received non-Athenian citizens and at the same time it was a sacred grove of Hercules (Long, 1996: 28). He was followed by Diogenes, who lived in a pot on the streets of Athens. Diogenes took Cynicism to its logical extremes, and 
came to be seen as the archetypal Cynic philosopher. He was followed by Crates of Thebes, who gave away a large fortune so he could live a life of Cynic poverty in Athens. Cynicism spread with the rise of the Roman Empire in the $1^{\text {st }}$ century, and Cynics could be found begging and preaching throughout the cities of the Empire.

The Cynics were spiritual descendants of Socrates, belonging to the school called "Minor Socrates", although they had received enough evidence from the Sophists as to their teaching method. For Antisthenes and his disciples, philosophy is purely secular wisdom (the first is said to be that "then the cities are lost when they cannot distinguish the bad guys from the good ones"), while virtue, although still it remains a purpose of life, it is something absolutely practical which does not need much talk or tedious training (Diogenes Laertius, 6, 2).

Goods are distinguished only in two categories, the outside (property, physical pleasure, luxury) and the interior. The second is that the philosophers' paramount demand, namely the secure knowledge of truth and the self, belongs. The Cynics, however, preach a "practical" ethics, in which virtue "paradoxically" does not depend on knowledge but it is the result of exercise, addiction and self-control. With a model of Heracles (Diogenes Laertius, vi. 2, 71), they call for personal self-sufficiency through the exclusion of so-called needs, as well as by walking into a natural way of everyday life, with simplicity, hardness and self-determination (Navia, 1996: 140). The "wise" of the Cynic is self-sufficient, having (by being) the wealth of all. By placing an emphasis on the daily way instead of the theory, the Ancients, Cynic descendants of the Antithynaus, traveled by a near-mural missionary from the extremity of the Hellenistic and Roman world, dressed poorly, with a shoulder bag to their little food, unconventional in all areas (as a rule, even denying those specific areas of socialism that were undoubtedly respected and honored by their founder Antisthenes), dirty, sloppy and provocative in their words and works, and established more a figure of attitude, form and behavior than an organized philosophical system (Cynics, n.d.).

\section{Conclusions}

Philosophy in Hellenistic era is intended to help a person who is confused with cultural and moral values through the transition to a new era to regain a sense of security based on himself and not on ideological or religious commitments of the past. Many have changed in socio-political organizations, education, art, leisure and material welfare of the Greek-speaking world. New choices are now open to people about their careers and new beliefs and ways of life are feasible. The cities have become huge, the populations are nationally complex, and the government is far from the lives of most people. The ancient Greek gods appear to many people too childish to be trustworthy, and very immoral to be admirable. Some people are attracted to foreign religions. There have been two centuries of scientific affairs and discovery. Every young man (but not every young woman) is free in Athens to listen to the lectures given by various schools of philosophy. Freedom of speech is almost absolute and people are not pressed to comply with the official religion of the state. The heroic ideal, as depicted in Homer's epics, is a distant past. It is not a world where people face the choices of Achilles and Odysseus (Long, 1996: 277).

All Hellenistic philosophical choices were inspired by Socrates. That is, all linked longterm happiness to intellectual honesty, to mental state and character, to the autonomy of everyone. They all claim that happiness "depends on us", or is in our power, regardless of how the outside world behaves (Long, 1996: 278).

A common element of the philosophers created in Hellenistic and Roman times is the connection of philosophy with individual life and its perception as an "art of life". Philosophy ends up being a driver of life and a source of relief, a healing art, a way to cope with a hostile world. From the $4^{\text {th }}$ century BC up to the first Christian centuries, Cynics, Stoics, Epicists and skeptical 
philosophers give a new role to philosophy. The wise or the philosopher with the ascetic or stoic way of life gives a new pattern and indicates the path of disregard and inner freedom for the achievement of individual happiness. The interest in politics is diminished and ethics becomes central. With Neoplatonism, the shift from the perceptible world to the super sensus is observed. Philosophy gains a "entertaining" character, trying to lead the soul to the infinity, to the deity (Nussbaum, 1994: 3).

\section{Acknowledgements}

This research did not receive any specific grant from funding agencies in the public commercial, or not-for-profit sectors.

The author declares no competing interests.

\section{References}

Becker, L. (2001). A new stoicism. Princeton: Princeton University Press.

Benatouil, T. (2009). Les Stoiciens III. Paris: Les Belles Lettres.

Graver, M. (2009). Stoicism and emotion. Chicago: University of Chicago Press.

Cynics (n.d.). Internet Encyclopedia of Philosophy. Retrieved from https://www.iep.utm.edu/cynics/

Long, A. A. (1986). Hellenistic philosophy, Stoics, Epicureans, Skeptics, $2^{\text {nd }}$ edition. Cambridge: Cambridge University Press.

MacGillivray, E. (2012). The popularity of Epicureanism in late-republic Roman society. The Ancient World. XLIII, 151-172.

Navia, L. (1996). Classical Cynicism: A critical study. Connecticut: Greenwood Publishing Group.

Nussbaum, M. (1994). The therapy of desire. Princeton: Princeton University Press.

O’ Keefe, T. (2010). Epicureanism. University of California Press.

Seddon, K. (2005). Epictetus' Handbook and the Tablet of Cebes. New York: Routledge.

Sellars, J. (2006). Stoicism. University of California Press.

Sharpe, M. (2013). Stoic virtue ethics. Handbook of virtue ethics. Johannesburg: Acumen Publishing.

Sharples, R. W. (1996). Stoics, Epicureans, and Skeptics: An introduction to Hellenistic philosophy. New York: Routledge.

Wilson, C. (2015). Epicureanism: A very short introduction. Oxford University Press.

Zeller, E. (1923). Die Philosophie der Griechen. Leipzig: O.R. Reisland. 